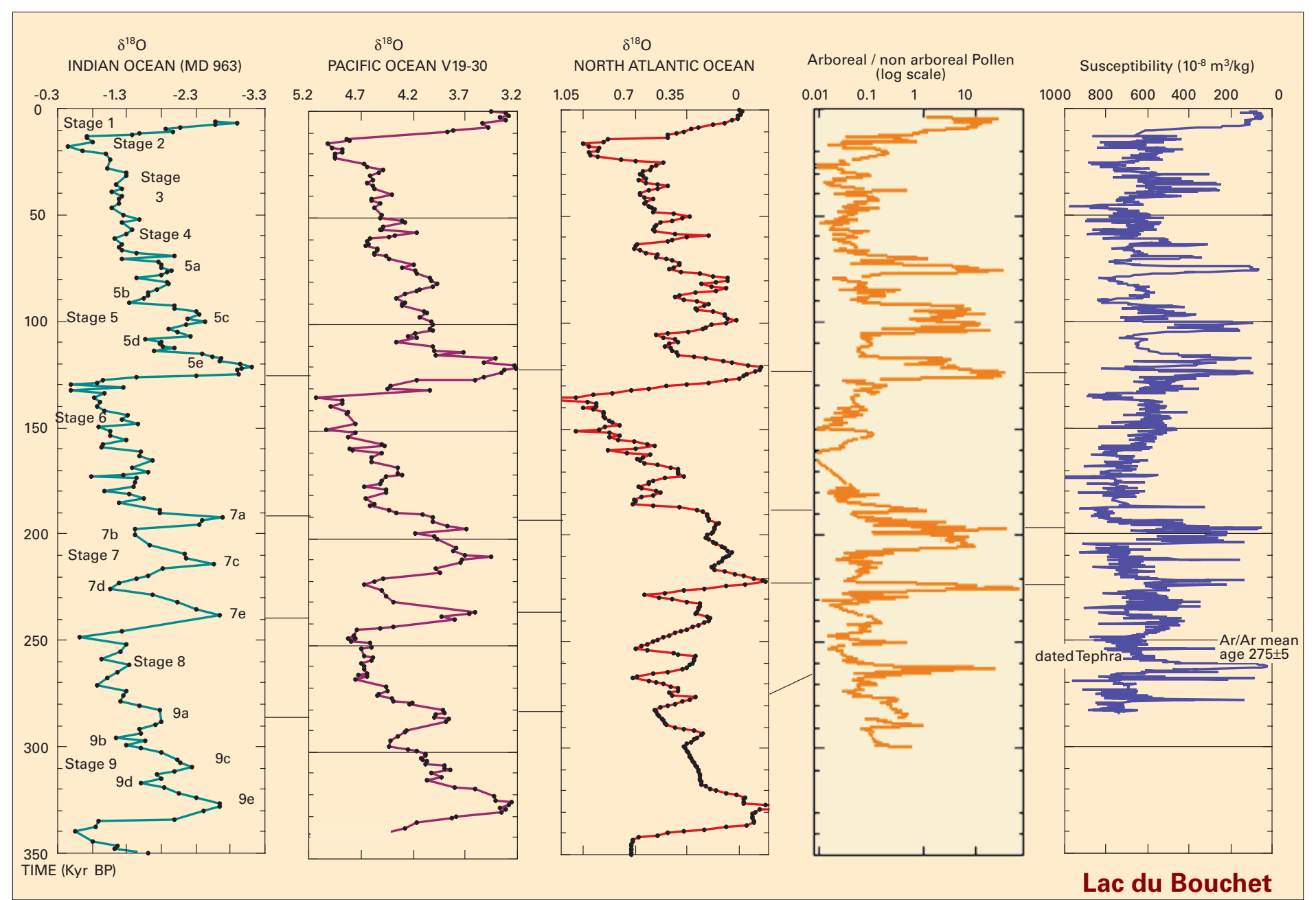

Figure 5: Pollen and magnetic susceptibility from Lac du Bouchet, compared with marine data.

\title{
A 300,000 Year Record from Lac du Bouchet, France
}

Volcanic activity on the Velay plateau (Massif Central, France) generated numerous maar-type explosion craters between the end of the Pliocene and ca. 800 kyr BP. These craters were subsequently occupied by lakes and filled by sediments; maar lakes thus contain thick records of climatic and environmental variations. They also received volcanic ash-fall from neighbouring eruptive centers. The Arboreal Pollen curve of the $40 \mathrm{~m}$ long sequence of Lac du Bouchet gives an idea of the alternation of forested and unforested vegetation. The simplified pollen diagram allows identification of five main warm complex units alternating with five cold episodes from the top (Holocene) to the bottom. Provided that authigenic magnetic minerals do not interfere, magnetic susceptibility measures the concentration of inherited titanomagnetite particles and, since dissolution provides a cumulative effect, susceptibility is tightly related to erosion regimes of the catchment area. High mineral/organic ratio during cold periods results in a high magnetic susceptibility, while low mineral/organic ratio during warm period results in low susceptibility. The chronology was established based on ${ }^{14} \mathrm{C}$ dating (Thouveny et al. 1994) and more recently on an Ar/Ar age at $42 \mathrm{~m}$ depth (Roger et al., 1999). High resolution oxygen isotope records from the Pacific Ocean (Shackleton, et al. 1985), Indian ocean (Bassinot et al. 1990) and North Atlantic Ocean (Vogelsang, 1995) are presented as reference.

The average age $275 \pm 5 \mathrm{kyr}$ BP obtained by Ar/Ar dating coincides with the Amargier interstadial and can be compared with the age of its equivalent in these $\delta^{18} \mathrm{O}$ records. Although this substage is marked in the Indian and Pacific Oceans, it is often considered as part of stage 8 . In our record, the increase of thermophilous trees, devel- opment of soils in the catchment area and deposition of highly organic gyttja suggest that it was rather similar to an interglacial stage. We thus propose to correlate the Amargier interstadial with a low ice volume substage occuring in this time window in the Oceanic records (substage 9a) and dated at 285.7 \pm 3.5 in the $\delta^{18} \mathrm{O}$ record of the vein of Calcite of Devil's Hole (Winograd et al., 1992, Ludwig et al., 1992, figure 8 this issue).

\section{Nicolas ThOUVEnY}

CEREGE, Aix-en-Provence, France nthouven@cerege.fr

Full references for this article can be found at www.pages.unibe.ch/ publications/newsletters/ref993.html 